\title{
A Árvore das Palavras
}

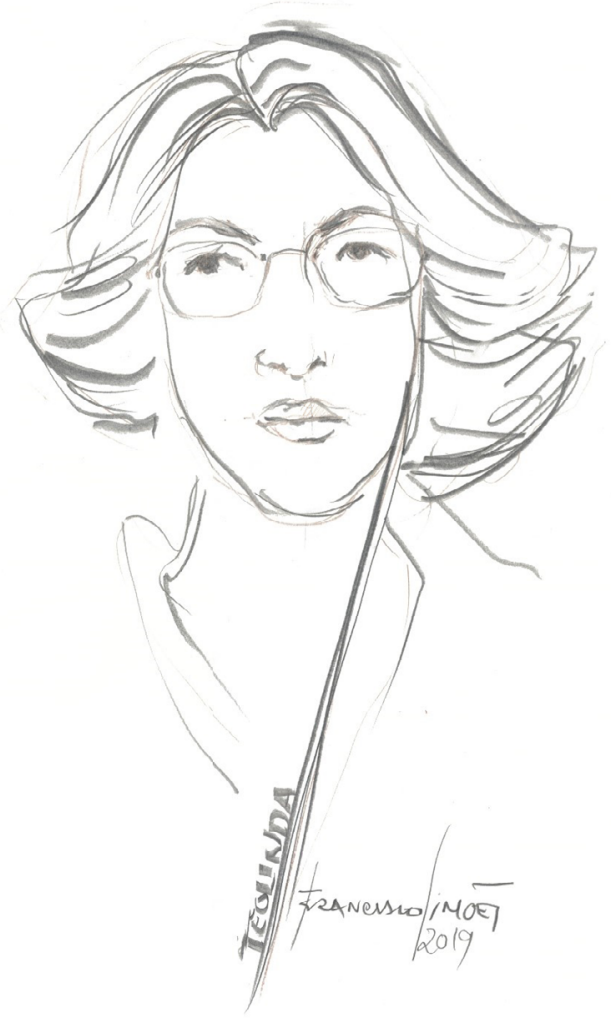

Teolinda Gersão - 40 anos de vida literária Exposição de pintura

Comissária: Isabel Ponce de Leão Coordenadora: Fátima Luz 
Em parceria com o CLEPUL (Centro de Literaturas e Culturas Lusófonas e Europeias, Universidade de Lisboa), a Cooperativa Árvore, no âmbito das comemorações internacionais dos 40 anos de vida literária de Teolinda Gersão (1981-2021), promoveu uma exposição de diferentes expressões artísticas em torno da obra da escritora.

A exposição intitulou-se $A$ Árvore das Palavras (título de um romance da autora - 1997; 2018) e os artistas que nela colaboraram enrouparam com outras linguagens a obra literária teolindiana. Os trabalhos expostos estavam ladeados de um aparato paratextual enformado por olhares críticos.

A actividade permitiu não só um estreito amplexo entre as diferentes linguagens de arte como também uma forte chamada de atenção para uma das grandes escritoras da actualidade.

Dela damos conta, não só através de pequenas reproduções das obras expostas, acompanhadas da ficha técnica, e das respectivas obras teolindianas que estiveram na sua génese, como também reproduzindo os textos críticos, numa tentativa de prolongar o tempo da memória.

Isabel Ponce de Leão
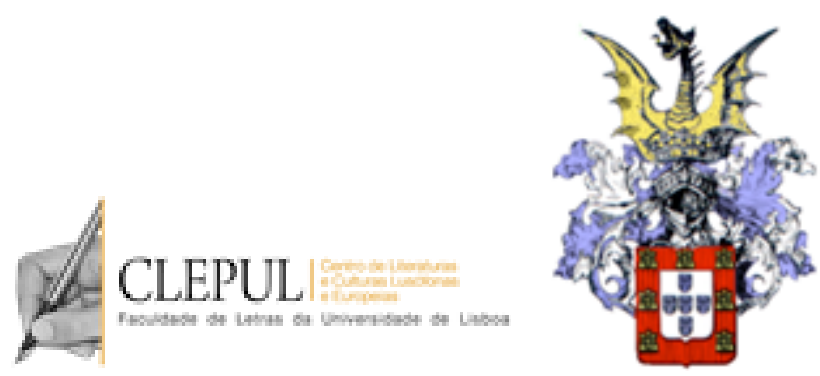

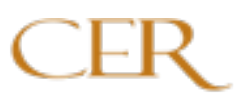

CENTRO de ESTUDOS REGIANOS ENTBDADE OE UTHIDADE POMICA

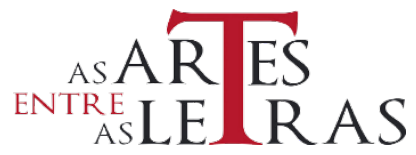




\section{Legendando imagens}

"Não chovia há muito tempo e tudo tinha começado a morrer Até as árvores e os pássaros

As pessoas tropeçavam em pássaros mortos

Tudo tinha secado

A terra abria fendas

Gretadas pela falta de água

A terra tinha feridas na pele

Animais morriam

Pessoas morriam

Crianças morriam

O ribeiro secou

O céu secou

As folhas torciam-se nas árvores

E depois também as árvores secavam [...]

Teolinda Gersāo, “A mulher que prendeu a chuva” (2007). 
1.

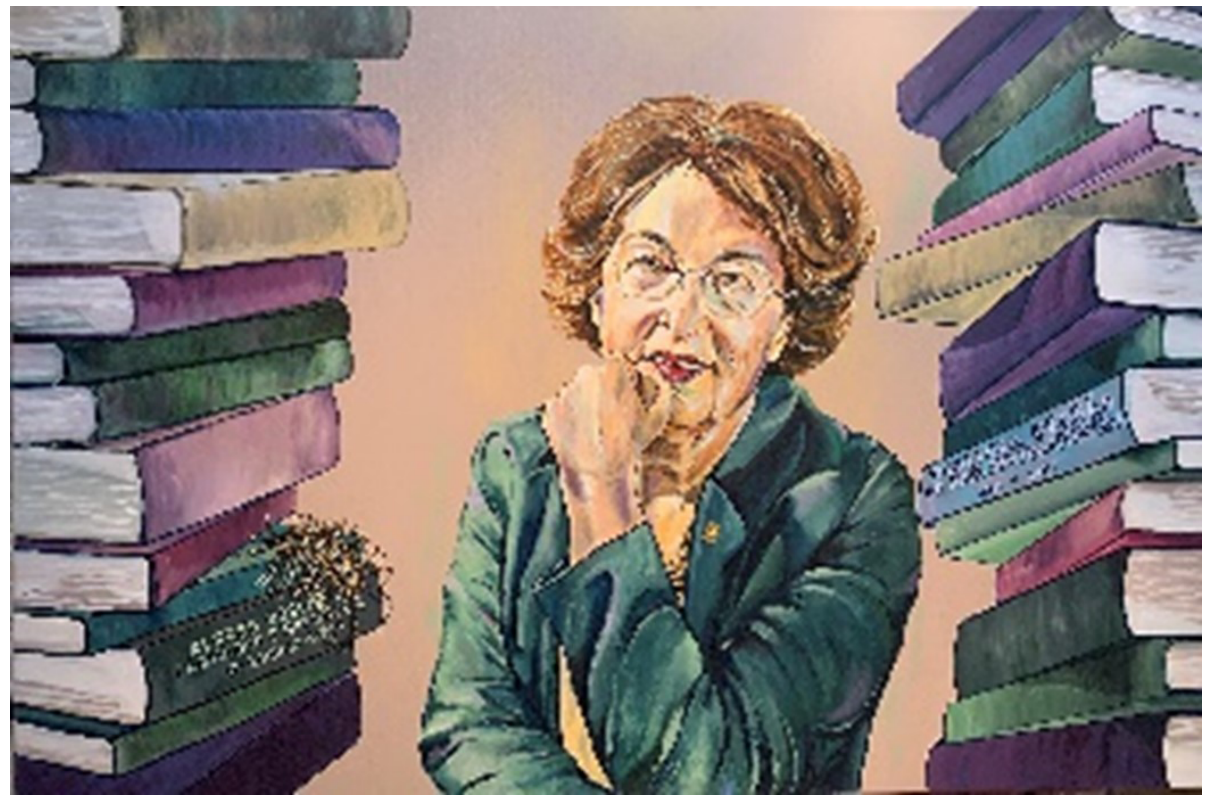

Figura 1 - Afonso Pinhão Ferreira, “Teolinda”, acrílico s/ tela, $150 \mathrm{~cm}$ x $100 \mathrm{~cm}$.

\section{Jamais passé}

Ao retrato, como registo da presença, aparência, e personalidade do indivíduo, é conferido um carater mágico. No caso do artista Afonso Pinhão Ferreira, a representação pictórica da autora Teolinda Gersão pinta as características físicas, mas também psicológicas, através dos elementos que circundam a figura humana. Motivo pelo qual o processo de observação desta obra, para o qual somos convidados, rejeita a perceção mais recente de que os retratos pintados em tela são passé, face às expressões artísticas que constituem a arte contemporânea.

$\mathrm{Na}$ arte contemporânea, o retrato é muito mais do que uma mera representação: já mudou na forma e recebe influências de diferentes movimentos artísticos como a arte abstrata, o minimalismo, ou a arte digital. Deste modo, o retrato pinta, também, o seu tempo e o contexto, a par da representação individual, seja através da pintura, da escultura ou da fotografia, ou ainda, outros media. 
Pinhão Ferreira retrata Teolinda Gersão não só como sujeito, mas também, e através dos elementos que inclui na tela, como um 'meio' para outros contextos: o da sua produção literária de quatro décadas, representada por vinte e cinco livros, já que o vigésimo sexto se constitui futuro, i.e., o livro que temos agora em mãos. Destaca o artista uma obra, numa leitura orientada pelo relógio do tempo, "Alfred Doblin - Indivíduo e Natureza. O Ensaio, 1979", título da tese da escritora, convocando para este texto-tela o contexto académico, juntando-se este ao mais evidente contexto literário. Teolinda Gersão sobressai tranquila, serena e segura de tais mundos, na pincelada do artista. No diálogo com o observador leitor da tela, o retrato convida a leituras Outras, desta feita, do universo literário.

Convocam-se ainda neste retrato miriópodes, do grego myriópous ou "que tem dez mil pés". E serão certamente milhares as páginas a percorrer no universo literário de Teolinda Gersão, outros tantos serão os universos ficcionais, os seus sonhos e as suas personagens, as vivências e os contextos que aqui celebramos.

A contemporaneidade da obra de Teolinda Gersão alia-se à contemporaneidade do formato do retrato de Afonso Pinhão Ferreira, num processo partilhado de construção da identidade da Mulher como Autora, e da Autora como Escritora de Mundos Outros, que permanecem tão atuais. A representação discursiva da Escritora aqui retratada tornase lugar e convite para a leitura da sua obra literária, tela feita narrativa CONtextos. Não há melancolia, há sedução, harmonia e serenidade neste convite à descoberta de outros Mundos e suas Narrativas.

Isabel Patim

Para Afonso Pinhão Ferreira 
2.

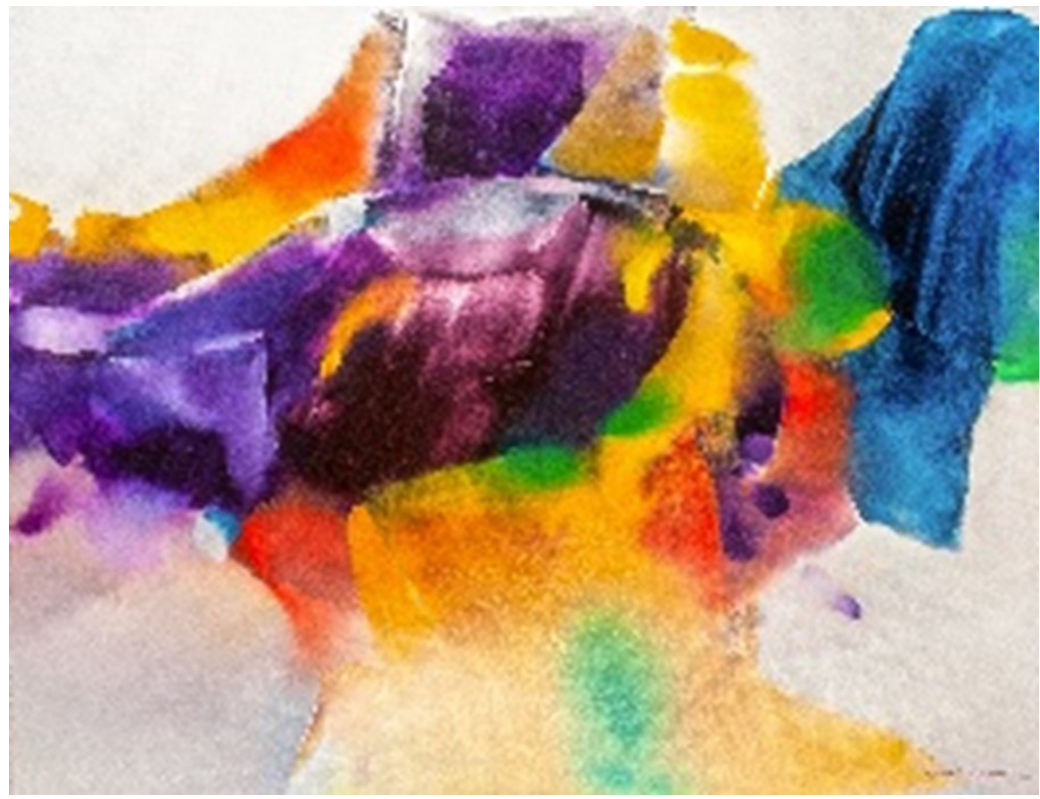

Figura 2 - Florentina Resende, "Silêncio", óleo s/ tela, $100 \mathrm{~cm}$ x 100cm.

Explorando os limites expressivos da sua linguagem plástica, Florentina Resende sintetizou numa composição pictórica os sentidos interpretativos nucleares da obra literária "Silêncio" (1995) de Teolinda Gersão, assim como as emoções que experienciou enquanto mulher leitora. A artista identificou-se com a fluidez narrativa do romance de Teolinda Gersão, transcrevendo a cadência narrativa com pinceladas rápidas e manchas de contornos parcialmente definidos. As manchas aveludadas, sensuais, evocando a sexualidade patente na relação amorosa dos protagonistas do romance, sugerem antropomorfismos identificáveis com esses personagens ficcionais, recorrendo a artista à simbologia da cor para transmitir os conteúdos de referência da obra.

Assim, as cores carmim tostado e violeta representam, segundo a artista, a insatisfação permanente da mulher (Lídia) na sociedade e vivida na relação amorosa com o homem (Afonso), criando um círculo subtil representando o Ser contido ou a Casa enquanto lugar tradicional 
da expressão do feminino. Um espaço arredondado, como um aquário, circundado por fragmentos que se expandem para fora do círculo, com vermelhos, amarelos e verdes, numa profusão e explosão do Ser, que se entrelaçam e fundem, simbolizando os diferentes discursos de género e o conflito entre a aceitação ou rejeição do papel tradicional da mulher.

No romance de Teolinda Gersão, a casa é sobretudo um lugar de reclusão/opressão ou proteção, muitas vezes o lugar comum do silêncio, do desejo de comunicação, e Florentina Resende usou o azul para exprimir a fuga e a superação na luta pela igualdade de oportunidades, direitos e deveres, por uma sociedade mais igualitária, justa, feliz.

Sérgio Reis

Para Florentina Resende

3.

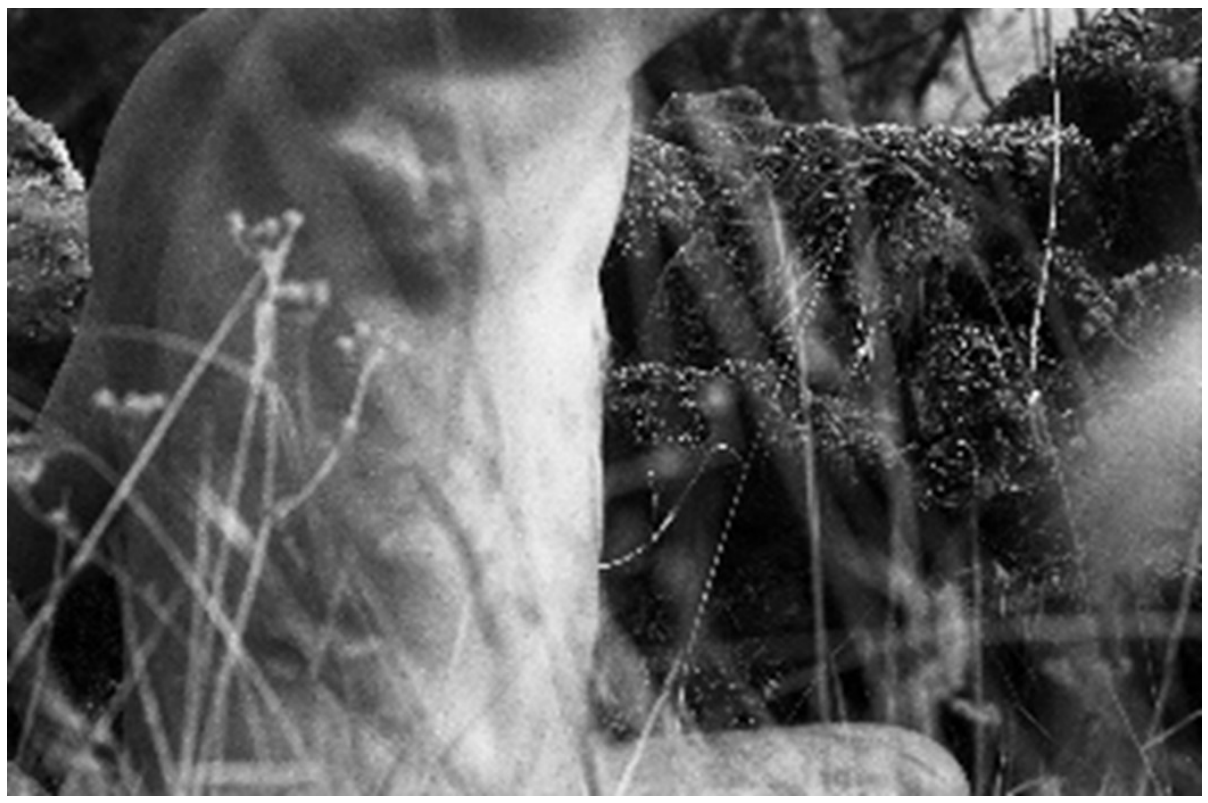

Figura 3 - Irene Gonçalves, "Homem natural”, fotografia analógica P\&B, $68 \mathrm{~cm} \times 100 \mathrm{~cm}$. 
Atrás da porta e outras histórias é um livro de contos de Teolinda Gersão de onde selecionei dois - Nascer e A criação de uma criatura - como ponto de encontro para a obra que apresento.

No conto Nascer Teolinda Gersão fala-nos de um lugar inicial livre e elevado, onde nos confundimos com ele e de um mundo inferior onde passamos a viver após nascer. Diz, na página 40, referindo-se a esse lugar inicial "Aqui tudo está imóvel e adormecido: no lugar do tempo há apenas um instante, sempre igual e sem fim". Acrescenta na página 41 "A vida lá em baixo é tão curta que cada momento só pode ser precioso: nenhum momento dura, cada um é único...".

Neste mundo inferior onde vivemos poderemos espreitar esse lugar inicial de que a escritora nos fala? Será a arte capaz de refletir sobre isso?

Pressinto uma certa analogia entre a minha fotografia e este conto. $\mathrm{Na}$ imagem que aqui mostro procurei um corpo que se confunde com as plantas, com as pedras e com os musgos, deixando-se pertencer a um todo natural. Também é muito breve o "instante decisivo" em que primo o obturador e fixo uma imagem que é sempre única.

A minha fotografia não poderá mostrar esse mundo anterior e "invisível para os olhos". Mas será capaz de questionar e olhar para um momento inicial da vida neste mundo inferior?

O que procuro na minha obra fotográfica, sobretudo nos últimos anos, é o ponto onde o homem se encontra com a natureza e, de algum modo, tento sublimar essa relação.

É o meu olhar (feminino) que revela um homem nu (masculino) em simbiose com a nudez da natureza (feminina). O que poderá nascer daí é a pergunta a que tento responder sempre que, eu e o modelo, vamos para o campo ao cair do dia, momento em que a inclinação da luz natural me poderá ajudar a criar as imagens que registo em preto e branco. Durante essa oficina, a minha sensação é a que Teolinda Gersão descreve na página 90 do conto $\boldsymbol{A}$ criação de uma criatura: “... é um objecto fugidio que parece pertencer-me, que me chama e exige que o reconheça, mas a cada momento se evade".

Não saberei falar da minha obra mas sei do meu fascínio pelo ser humano e pelo seu corpo, do meu deslumbramento pela natureza e da minha perplexidade perante a vida que está sempre a acontecer.

Irene Gonçalves

Para Irene Gonçalves 
4.

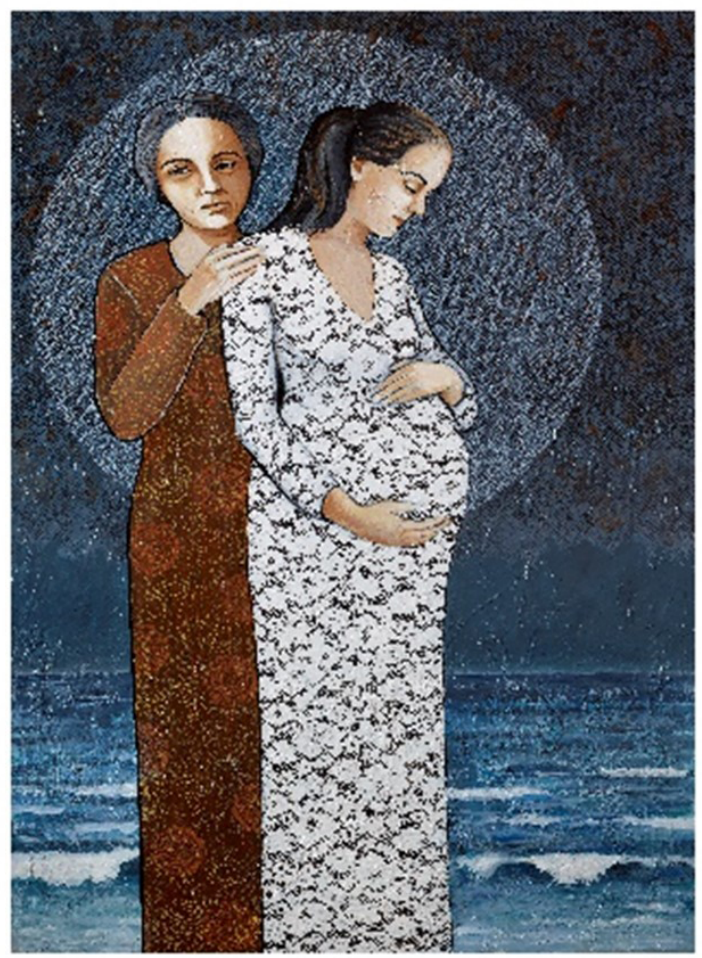

Figura 4 - Rosa Bela Cruz, "Mulher com paisagem e mar ao fundo", técnica mista s/ tela, $150 \mathrm{~cm}$ x $100 \mathrm{~cm}$.

Uma mãe perde o seu filho na guerra. Essa mãe é Hortense e na voz que arranca das entranhas cabe quase tudo: dor, angústia, revolta, raiva, impotência, desespero, perda, pavor, solidão, ansiedade. E o vazio, o imenso vazio.

É este o ponto de partida para 'Paisagem com mulher e mar ao fundo', romance de Teolinda Gersão cuja primeira edição remonta a 1982.

O conflito psicológico marca o ritmo da narrativa, manta de retalhos (des)construída ao sabor da memória, território inesgotável de contornos imprecisos e de tempos sobrepostos, onde a história e a História se cruzam a par e passo, tecendo um quadro complexo, aberto a outros discursos e interrogações. 
Dotada de uma enorme força interior, Hortense questiona permanentemente o sentido da vida. Não desiste, resiste. Na sua voz ecoam as vozes de todas as mulheres inconformadas que nela se reconhecem. A voz de um país em busca de si mesmo.

Ao perder Horácio (o marido), Hortense perdeu o seu chão. Veio depois o mar, esse mar falso, outrora promessa de aventura e de fortuna, agora sinónimo de despedida e de morte. Levou-lhe o filho.

Nos bastidores da tragédia está OS, acrónimo de Oliveira Salazar, sombra que paira sobre a existência, epítome de um regime opressor, espécie de pesadelo longo e escuro, devorador de homens e de vontades. Acabará por cair.

A outra mulher do romance é Clara. O nome não terá sido escolhido ao acaso. Exausta, carrega no ventre a criança de Pedro, o filho de Hortense estilhaçado por uma granada. Separadas pela dor, a tensão entre ambas é crescente e palpável.

Mas o fruto desse amor brutalmente interrompido irrompe como um raio de sol por entre as trevas, promovendo o reencontro destas duas mulheres. Uma nesga de esperança capaz, quem sabe, de fazer renascer a capacidade de amar. De acreditar.

$\mathrm{O}$ universo feminino não é um território estranho à obra de Rosa Bela Cruz (pintora tal como Hortense), que a ele tem voltado de forma recorrente ao longo dos últimos anos.

No pleno uso da sua liberdade criativa, a artista recria na tela este reencontro, fundindo a imagem das duas mulheres, recuperando referências caras à história de arte: a lua, símbolo da fertilidade feminina, assume o lugar do halo, de tradição bizantina, que atravessou a arte ocidental. Contra ela, recorta-se a figura de Clara, a fazer lembrar a Senhora do Ó, designação popular para a imagem da Virgem expectante condenada pela Contra-Reforma. A vida (e, por extensão, o país) abre-se ao futuro. Desponta finalmente a cor.

Natural de Ovar e com um longo percurso dividido entre o ensino das Artes Visuais e a pintura, Rosa Bela Cruz integra a galeria de artistas convidados pela Cooperativa Árvore a participar nesta exposição nascida do casamento entre a literatura e as artes plásticas, para assinalar os 40 anos da obra literária de Teolinda Gersão.

Cristina Cordeiro

Para Rosa Bela Cruz 
5.

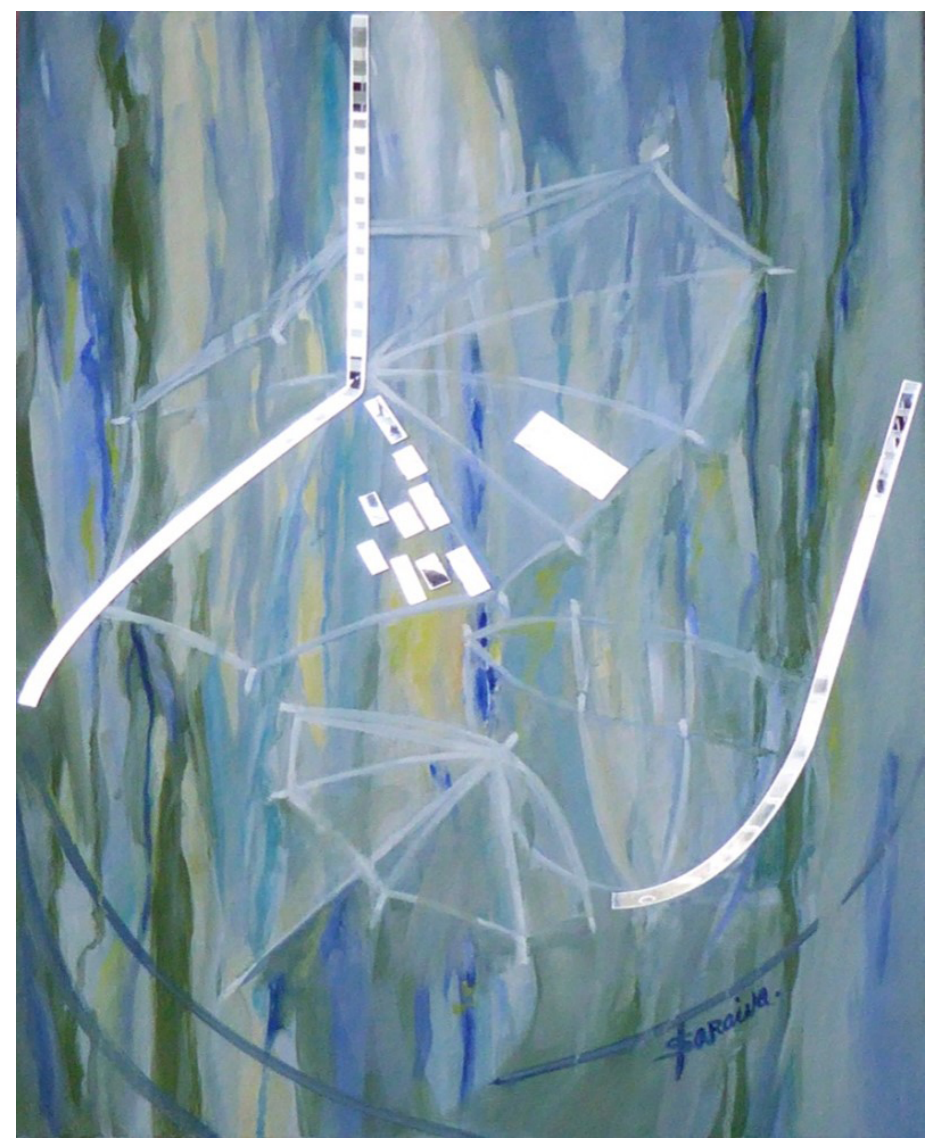

Figura 5 - Isabel Saraiva, “Os guarda-chuvas cintilantes”, óleo s/ tela e espelho acrílico, $50 \mathrm{~cm} \times 70 \mathrm{~cm}$. 


\title{
Em passo de dança, cintilam as cores!
}

\author{
"Traço de arco de uma ponte \\ comércio de olhares \\ - rostos serenos" \\ Isabel Saraiva
}

\section{Teolinda Gersão e Isabel Saraiva.}

Duas mulheres de imagens. Duas mulheres de palavras. Duas mulheres de pontes: pela imagem, pela palavra. Denominador comum: a sensibilidade e a força. Da imagem Da palavra.

"Os guarda-chuvas cintilantes" de Teolinda, são leves e transparentes na Isabel. O diário/não diário da escritora, as suas observações e reflexões das horas que os dias levam tempo fora, são os azuis, os verdes, as águas e os céus de Isabel.

Em Teolinda: "A História começa onde começa a escrita. Escrevo no cimo da folha de papel. /Antes, é apenas um tempo informe e sem medida". Em Isabel, a pintura nasce "sob a pele". A cor vem da infância. A água, que purifica e que dá a vida, é o elemento presente: visível e invisível, dizível e indizível.

O traço das letras de Teolinda une-se ao traço das pinturas de Isabel em diálogo de espantar e em comunhão de sentidos, de que resulta uma nova narrativa impressionista; como se a linguagem, o silêncio, as dúvidas e o "eu" de uma aportassem por magia, na outra!

A escritora levanta, de forma ímpar, nesta obra, questões sobre a verdade, a verosimilhança, a ficção, a autobiografia, a diarística, o diário...

A pintora dá-lhes uma identidade misteriosa através da cor, da forma e da luz. Uma cor suave de muitos tons, porque múltiplas são as emoções que cintilam com os guarda-chuvas. E na beleza da ponte que a todos une, há fadas, sábios, e gente comum que dançam para chegar à margem da harmonia entre a palavra e a imagem.

Nesta tela, nesta página de leitura "cintilante" está "proibida a entrada a quem não andar espantado de existir”!

Nassalete Miranda

Para Isabel Saraiva 
6.

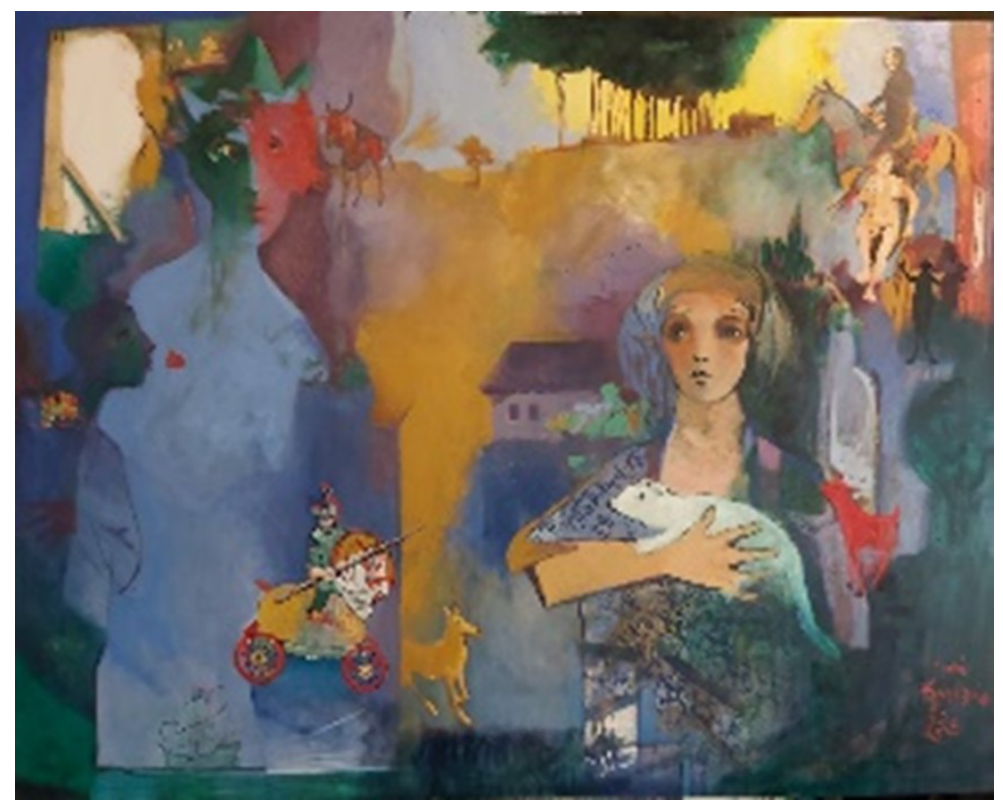

Figura 6 - José Emídio, "O Cavalo de Sol - Figura com Arminho", óleo s/ tela, $114 \mathrm{~cm} \mathrm{x} 146 \mathrm{~cm}$.

Como um corcel...

se agarra a vida: a "passo", a "trote", a "galope" ou a "salto". Por agora em crescendo sem que diatribes desviantes sejam pospostas. Vejo a mansão ribatejana albergadora de desejos e sentimentos por vezes antinómicos, viciado axis mundi de Vitória e Jerónimo. Ela, a actriz em movimento; ele, o espectador estático. Ela cavalga; ele observa.

Há uma simbólica cromática que vincula à terra, num penitente desafio aos elementos sem que se deixe de imbricar a sua relação com o homem. Emoções e sentimentos surgem da subversão de planos perseguidores da ilusão do real. Recuo a Friedrich e a Corot; passo em Monet, Whistler, Peploe e Derain, mas é em José Emídio que me detenho.

Com um elevado sentido de narratividade transporta para a tela $O$ Cavalo de Sol de Teolinda peregrinando por lendas e mitos em espaços fluidos de ingenuidade e apostolado. Evocação de uma metahistória reivindicadora de (re)conciliações: o real persegue o imaginário; 
o prosaico acossa o grandioso. Segue-se a vertigem de encontros improváveis. Também Vitória se cruzou com Amaro e Jerónimo com Melícia! A soturnidade e a alegria em amplexo a prazo.

Há todo um devaneio mitificado no contraste cromático com destaque para o azul de onde brota a metáfora da liberdade.

Indomável Vitória... indomável corcel porque "Era ela que se julgava o sol, [...]. A esse papel, e não a ele, ela amava. Porque lhe dava a ilusão de poder tudo."

Duas linguagens desbloqueiam o missionado da libertação. A "passo", a "trote", a "galope" ou a "salto", O Cavalo Azul tornado corcel.

Isabel Ponce de Leão

Para José Emidio

7.

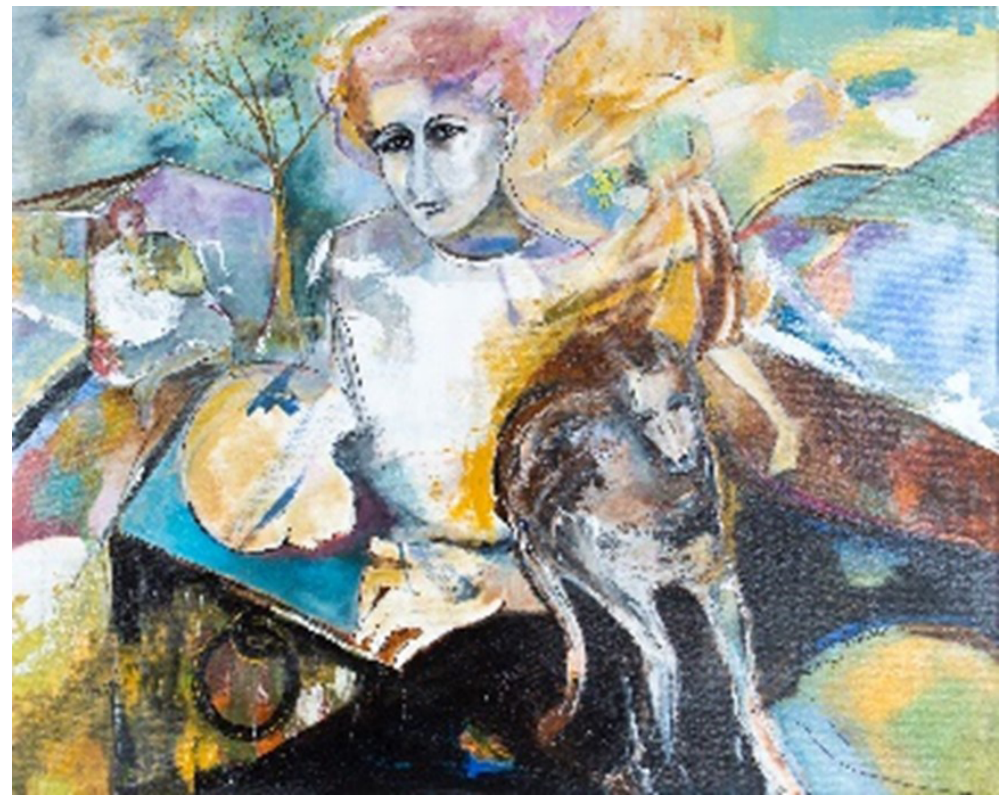

Figura 7 - Júlia Pintão, "Havia aquela presença, à sua volta, e o trote agora cadenciado do cavalo, que imitava o ruído de um coração batendo.", acrílico s/ tela, $100 \mathrm{~cm} \times 120 \mathrm{~cm}$. 
Que cores? Que formas transporta o nosso pensamento até poder transformá-las em matéria? Olhamos na tentativa de desvendar a cor de cada forma. É então que nos apercebemos de figuras que até sabemos nomear. Figuras que parecem querer escapar ao nosso escrutínio, envolvidas numa espécie da vibração cromática demasiado agarrada à terra. Vestida de branco, a figura central recusa ao espectador o olhar dos seus olhos negros. Alheados e, todavia, cúmplices da paisagem que os rodeia, esses olhos são os verdadeiros guardiões dos pensamentos envoltos na cabeleira fulva.

Manuela Bronze

Para Julia Pintão

8.

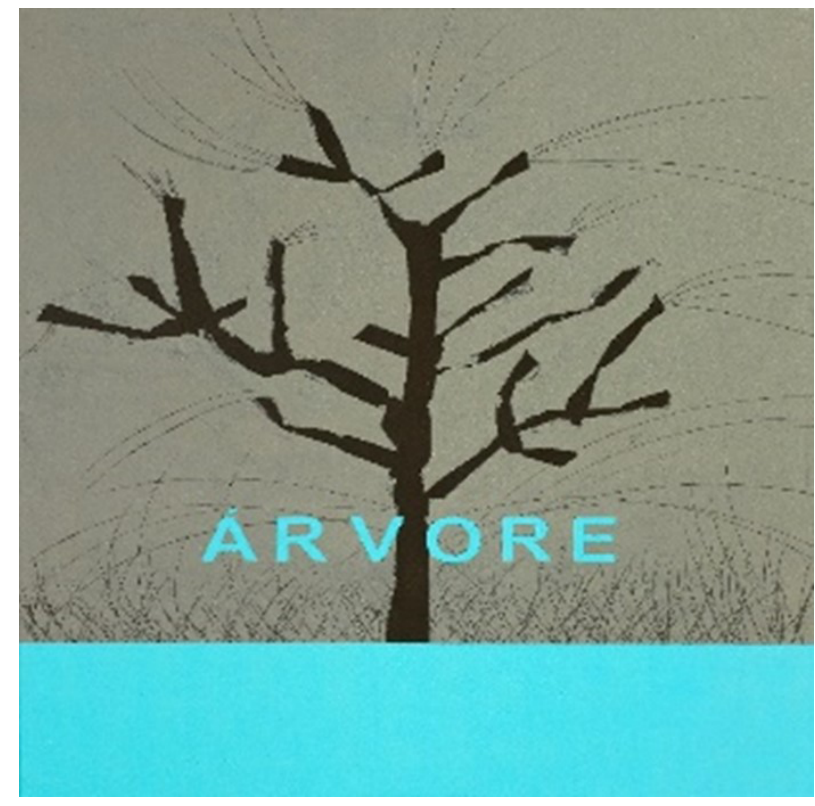

Figura 8 - José Rosinhas, “Árvore 2020”, acrílico s/ tela, $100 \mathrm{~cm} \times 80 \mathrm{~cm}$. 


\section{A Árvore das Palavras}

Olho a tua Árvore soletro-a e sinto o continente africano. Decomponho-a e os ramos erguem questões de identidade, consciência étnica, classe e género. Bebeste em William Hogarth a ideia de utilização da arte para comentário e crítica de questões sociais, económicas, políticas e mesmo ecológicas. Reivindicas, na actualidade nomes como Anselm Kiefer e Michael Sandle. Teolinda Gersão deu-te o mote numa outra linguagem. E tu, porventura galvanizado pelo Orientalismo de Edward Said, persegues as tendências do Pós-Colonialismo.

Esta é a tua resposta a Árvore de Palavras e às denúncias nela contidas. Uma resposta com esperança. Olho de cima para baixo e vejo desolação, sede, isolamento. Vou descendo, cautamente, e surgem pontes, muitas pontes. $O$ cinza e o negro cedem a um azul celeste imbricado com a mística do verde. Líquido amniótico de que essa Árvore emerge. O percurso do olhar é agora inverso; o poder cromático vivifica os ramos alongados para o parco infinito ao alcance da humanidade, porque "Não somos nada, poeira no vento, silhuetas minúsculas, na imensidão da paisagem”.

Foste com Teolinda a Moçambique, a África por metonímia, e colheste as preocupações locais. Imigração e guerra; identidade e étnia, fome e opressão... Não passaste as mãos no milenar lavatório de Pilatos, antes te comprometeste e enformaste o compromisso numa Árvore de promessas.

Gosto da opção pelo fragmentário e pelo simbólico pois tão bem casa com o estilo da também autora de $O$ Silêncio (1981) que ouço no teu apelo a esse promissor e paradoxal continente. Conseguiste numa, apenas aparente, estética do inacabado moldar ilogismos na tela. Usando a técnica mista, viabilizaste pontes. A miscigenação é, por ti e em ti, mais do que realidade.

Ontem, lendo Le Petit Prince de Antoine de Saint-Exupéry ouvia o Babobá e "falava com o vento e as folhas. A árvore abanava os ramos e eu pensava: a árvore das palavras." Assim a pintaste e esse verde-água de esperança é elo unificador da Casa Branca com a Casa Preta. À sua sombra, Amélia e Rodrigo não repudiam Gita e Laureano: "Eu sou, dizia a árvore agitando os ramos, a semente abrindo no escuro, a água apodrecendo nas lânguas, a floresta dormindo. Eu sou”. 
Tu és o pintor. Teolinda é escritora. Epifanias da convergência das artes que, de forma triádica, demandam a vida.

Isabel Ponce de Leão

Para José Rosinhas

* Título do livro de Teolinda Gersão (1997) motivador da tela de José Rosinhas. As aspas assinalam expressões que dele são retiradas.

9.

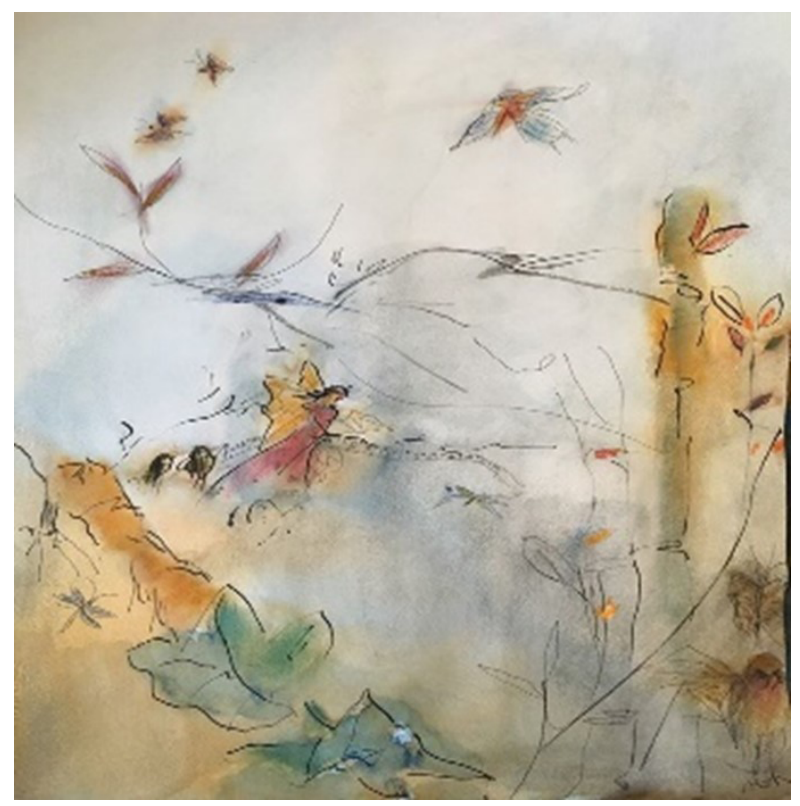

Figura 9 - Antónia Gomes, “Julia”, aguarela s/ papel, $50 \mathrm{~cm} \times 40 \mathrm{~cm}$.

JÚLIA Na Tela de Antónia Gomes vemos a sua Júlia elevar-se pelo meio de Anjos, movendo-se no bosque do imaginário, flutuando entre pássaros surpreendidos e borboletas desorientadas, transportando o papel vegetal do teclado de musica da Júlia de Teolinda Gersão que 
rezava por Mozart, num rasgo de liberdade comum ás duas, “atrás do som interior como atrás de uma luz, com a sensação desesperada de não a poder alcançar nunca" como refere a Escritora sobre a sua Júlia. Há em Júlia de Antónia Gomes um mundo complexo narrado, na Tela, com os seus tons naturais, numa harmonia delicada de verde, castanho e azul, por onde vagueiam riscos finos de partitura, numa idêntica harmonia de sons que se sobrepõem "no instante para formar uma unidade" (Teolinda Gersão). As tonalidades de azul manchado, por onde a Júlia da Pintora esvoaça, sugerem a viagem de Júlia de Teolinda, a de Mozart, entre o caos e o cosmos do Universo ordenado pelo numero, numa "relação entre a estrutura do cosmos e a da musica" no dizer da Escritora. Na Tela, há um movimento ascendente que realça da composição, onde parece que todos os seus elementos se desenvolvem para o infinito e que vai ao encontro da harmonia superlativa transmitida pela musica nos instantes supremos. A Pintora, na sua Júlia, é livre nos elementos, é livre no traço e é livre na cor, numa justa homenagem á aluna e ao seu professor Claudemiro Palrinha, personagens de liberdade absoluta, mas, também, a Rogério Souto que não teve tempo de encontrar o livro prometido á Júlia do Teclado de Piano, que rezava por Mozart. Antónia Gomes usou a palavra de Teolinda Gersão e, com subtilidade, transformou-a numa mescla de manchas de cor e de traços delicados, ambos carregados de magnetismo impulsionado pela diferença entre a pintura e o desenho.

Jaime H Vieira dos Santos

Para Antónia Gomes 
10.

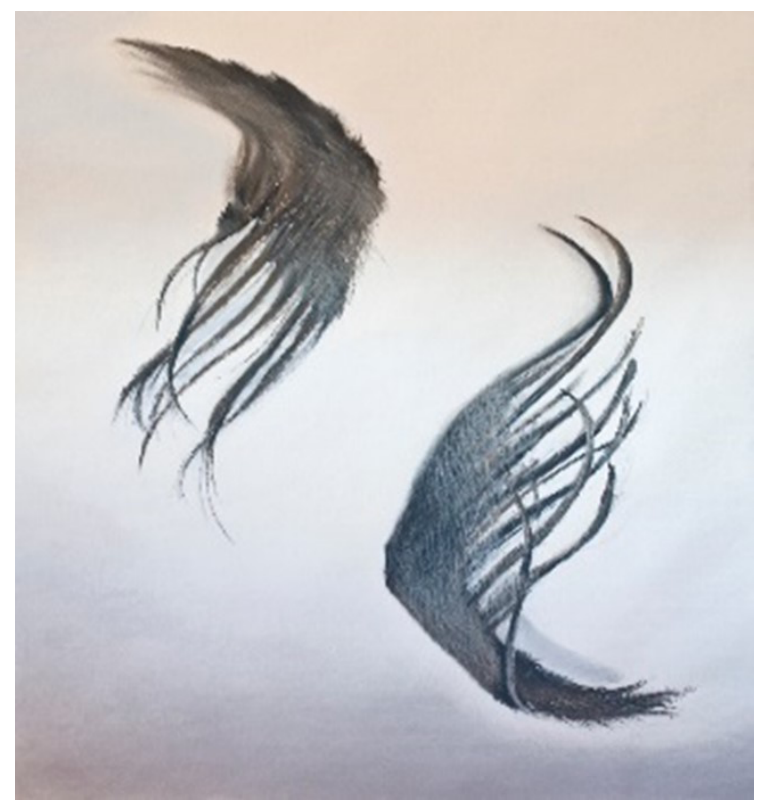

Figura 10 - Luísa Gonçalves, “Anjos - 2020”, tec. mista s/ contraplacado, $80 \mathrm{~cm} \times 50 \mathrm{~cm}$.

\section{A arte e os anjos. Luísa Gonçalves depois de Teolinda Gersão}

Recebi um desenho de Luísa Gonçalves. Chegou por correio electrónico. Vinha num anexo que utiliza um compressor de imagem, vulgarmente referido como jpg. É um belo desenho a pastel, escuro, de minúcia e cuidado técnico, formado por dois elementos soltos, lançados na vertical sobre o suporte em tela. São duas figuras que vagueiam, esvoaçam, pairam num espaço vazio. Não sei o que são estes dois elementos. A artista diz ter-se inspirado em algo muito concreto: folhas de palmeira, mas sugerem outra coisa: asas. Coisa concreta no mundo natural, se pensarmos nos pássaros, abstracta se pensarmos nas criaturas aladas que pertencem ao fantástico.

O desenho foi realizado em confronto com uma novela de Teolinda Gersão intitulada Anjos. Foi feito depois da sua leitura, leitura que eu fiz 
também. Na novela há duas partes. Uma em que tudo parece concreto e material, subordinado aos elementos. Desde o início que a presença do fogo e das chamas é avassaladora, mas a água domina, igualmente, numa aldeia inundada, num poço, num rio para o afogamento, no som que faz ao correr, no choro convulsivo. Também a terra se impõe, as árvores e a sua sombra, a madeira em combustão, o lugar dos que fogem e se escondem. Na outra parte da novela, é o imaterial que irrompe no céu, no sol e nos vitrais de uma igreja. Tudo se torna elevação, tudo é volátil e aponta para o alto. E há espíritos, serafins, querubins e anjos que se insinuam entre as personagens de carne e osso. E estas renascem.

Percebo agora o diálogo entre o desenho e a narrativa e o modo como a indeterminação e a ambiguidade guiam a criação e conduzem a apreensão do objecto artístico. Durante o tempo de observação do desenho, ocorrem muitas coisas: olhamos, descodificamos, identificamos o que está representado, ignoramos, invocamos outras realidades e voltamos ao início.

Intermediários, diz-se dos anjos que ligam o universo terreno ao universo divino. Mediadoras, diremos das obras de arte porque a arte não é a matéria, mas o que esta desencadeia. A arte está nesse intervalo entre o que nasce pela mão de escritores e de pintores e o que renasce nos nossos olhos, no nosso entendimento, no nosso sentimento. A arte está para lá das fronteiras dos objectos e dos dispositivos em que se concretiza, está na conjectura, na imaginação e no sonho. A arte é o que se gera a partir destas vinte e sete páginas de texto impresso de Teolinda Gersão e desta tela de Luísa Gonçalves. Anjos, portanto.

Laura Castro

Para Luísa Gonçalves 
11.

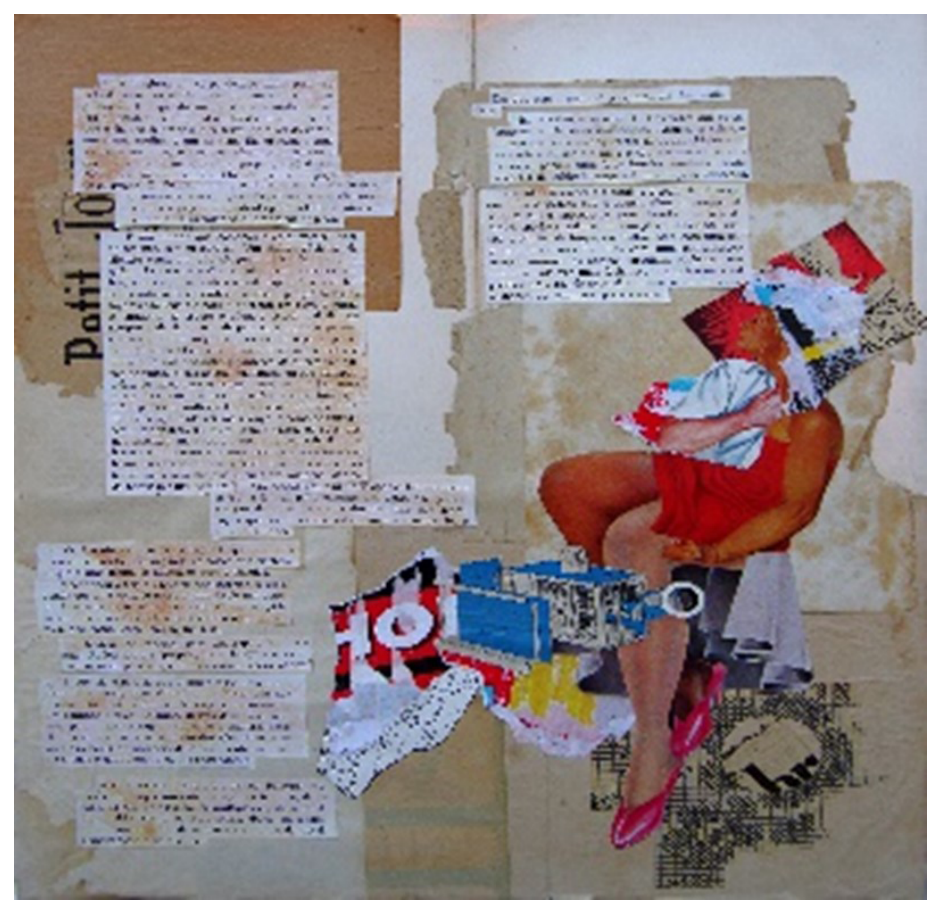

Figura 11 - Isabel Patim \& Raf Cruz, "Diálogos em Silêncio", técnica mista (textualidades \& colagem), $50 \mathrm{~cm}$ x $60 \mathrm{~cm}$.

\section{Gestão de $\boldsymbol{O}$ Silêncio}

Subjaz um pensamento transdisciplinar na colagem $O$ Silêncio obra homónima da narrativa de Teolinda Gersão; derrubados os muros, o diálogo interartes flui na construção de sentidos, sobretudo pelo não dito, que se afirma numa justa poética de entrelinhas de forma assaz volátil. Esta volatilidade dialógica persegue, sem disfarces nem ingenuidades, as instáveis relações humanas aqui configuradas nas ligações Lídia / Afonso e Lavínia / Alfredo. De repente, evoco Amor Líquido (Zygmunt Bauman) e vejo nos textos linguístico e plástico a efemeridade dos afectos, as histórias de amores e desamores, a flutuação sentimental, a 
rejeição do papel tradicionalmente feminino, o desejo de evasão oriundo do "mal-estar contemporâneo", para o que contribui a falta de domínio de códigos de subjectividade e poder. "Adeus" e "gato" são signos que Lavínia recorda do russo, e com eles o símile de uma falsa identidade em trânsito: chega, está, salta e parte; o gato espreita de cima do muro. Isabel Patim e Raf Cruz ascenderam ao muro e aí permaneceram recreando a história da história pelo transporte de elementos do discurso literário para o plástico. Uma iconografia abrangente, e aparentemente impessoal rejeita a auto-expressão, surgindo a paródia com símbolos do consumismo, da celebridade e da cultura de massas. Postulando-se no domínio da Pop Art, escoltam-se na Teoria Institucional da Arte de George Dickie, alteram materiais e buscam a ubiquidade explorando a percepção consciente do papel que é criar imagens na sociedade, um pouco na senda de Warhol ou Hamilton e mesmo de Tracey Emin. Evoco ainda a teoria do simulacro de Baudrillard e sinto-me afastada do texto original. Aproximo-me e vejo com o pensamento. Chama-me a atenção o texto linguístico na sequência de cima para baixo, da esquerda para a direita. Releio-o. Volto às colagens e surge uma parafernália simbólica: sapatos vermelhos, caixa de vidro, mulher quase desnuda... Do corpo da mulher surge um homem. Afonso, pergunto-me. Apesar de tudo, o silêncio é devorador; o passado e a memória são evocados nas cores do papel; mas surge o vermelho dos sapatos e do pano em fuga da tela, despertando para a actualidade de uma narrativa literária que, datada de 1981, cavalgou o tempo. Motivos que gerem o silêncio contando uma história de amor na geração do vale tudo, corroborador do ecletismo, da pluralidade e da auto-percepção; a meta narratividade faz todo o sentido... Os artistas — todos os artistas — acreditam que o amor é "uma ponte para outra coisa" muito além do Amor Líquido.

Isabel Ponce de Leão

Para Isabel Patim \& Raf Cruz 
12.

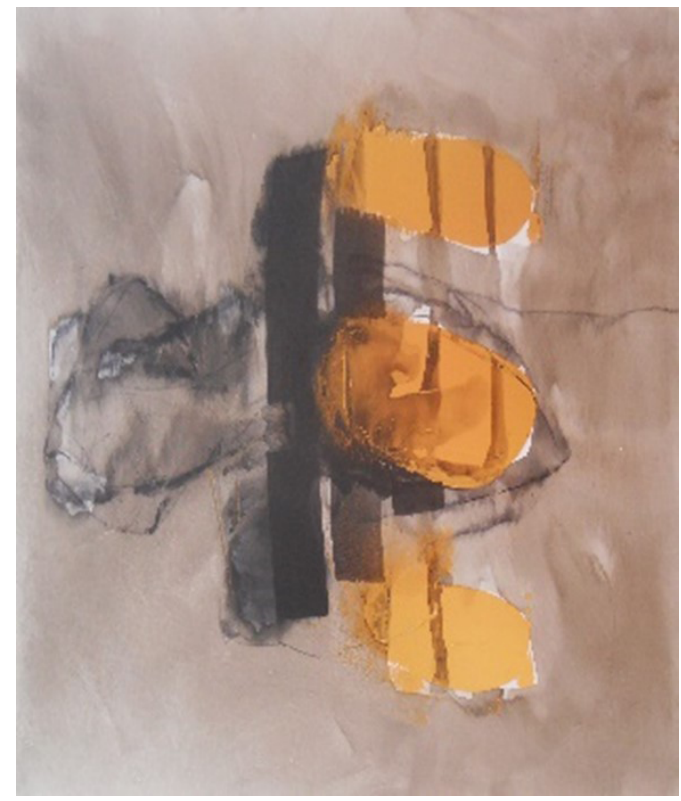

Figura 12 - Henrique do Vale, "Dimdas - 2020", acrílico s/ tela, $130 \mathrm{~cm} \times 80 \mathrm{~cm}$.

\section{Dindas e o renascer da humanidade em cinzas}

Henrique do Vale, treze anos depois, encontra as Dindas, em forma de premunição e salvação, pintando em tela sobre acrílico tudo o que "A Primavera nāo sabia..."

Representa-nos a capacidade de regeneração de toda uma Terra e de Bichos que não se compadecem do pensante, do Homem, na sua avidez pela posse da "matéria"

Esse desgraçado que se auto destrói ao mínimo toque de um ser ínfimo, qual pérfido diabo, obrigando-nos a questionar o que somos verdadeiramente, o que fazemos, que caminho e que sentido queremos para as gerações futuras e para o planeta que ainda acolhe a nossa espécie. 


\section{Dindas I}

Três pepitas de ouro de Ashanti, arrancadas com a força bruta do homem ao útero gigante, fértil e bondoso das terras de uma África quente e rica na génese da nossa existência

Também de África o pintor trouxe consigo os sonhos em neblinas trespassadas de cor, fantasia e alegria

Enquanto menino, o Henrique não sabia, mas foi guardando em si a força, o brilho e o fulgor das pepitas de África que o viu nascer.

\section{Dindas II}

Mas a Primavera nāo sabia ...

Três Crisálidas em casulo de ouro, prontas a ecludir

A metamorfose, o renascimento das flores, das árvores, das plantas, dos animais, do Homem

O Henrique também não sabia..., mas leva-nos sempre a um mundo de esperança, à Primavera das nossas vidas.

Maria Elisa Braga

Para Henrique do Vale 
13.

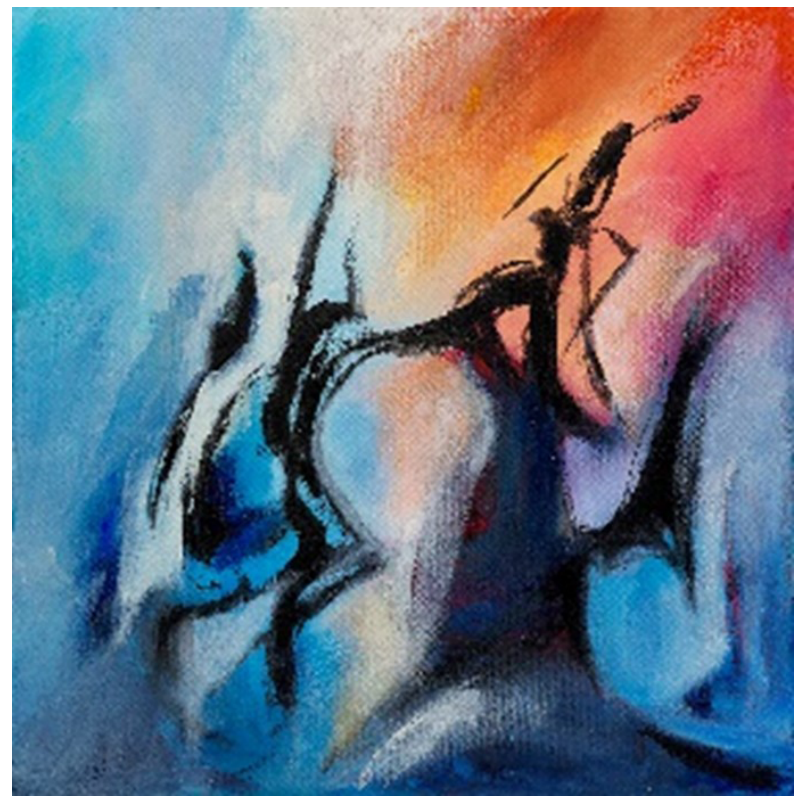

Figura 13 - Manuela Mendes da Silva, "Sem título", acrílico s/ tela, $100 \mathrm{~cm} \times 100 \mathrm{~cm}$.

Agora o coração está a borbulhar. Arde tão bem, a chuva. Sobretudo Se é uma escritora a tecer a narrativa Ou uma pintora a dar-lhe o aparato

De a ver assim a correr sobre os azuis.

De muitas mãos se faz um só olhar, De muitos sortilégios e magias.

E a chuva beneficia muito quando cai

Sobre as nossas cabeças fascinadas Pelo o que é do mundo e em mundo Se transforma pela força criativa Que mantemos. Voltemos à leitura, 
Voltemos à pintura do que alastra

$\mathrm{Na}$ exígua dimensão da galeria.

Por estas páginas e por este quadro intenso

Possuímos o que é quase inatingível

E cresce para sempre como arte

De transformar as coisas noutras coisas.

Agora o coração está a borbulhar.

Sabe tão bem, a arte. A nossa chuva.

Amadeu Baptista

Para Manuela Mendes da Silva

14.

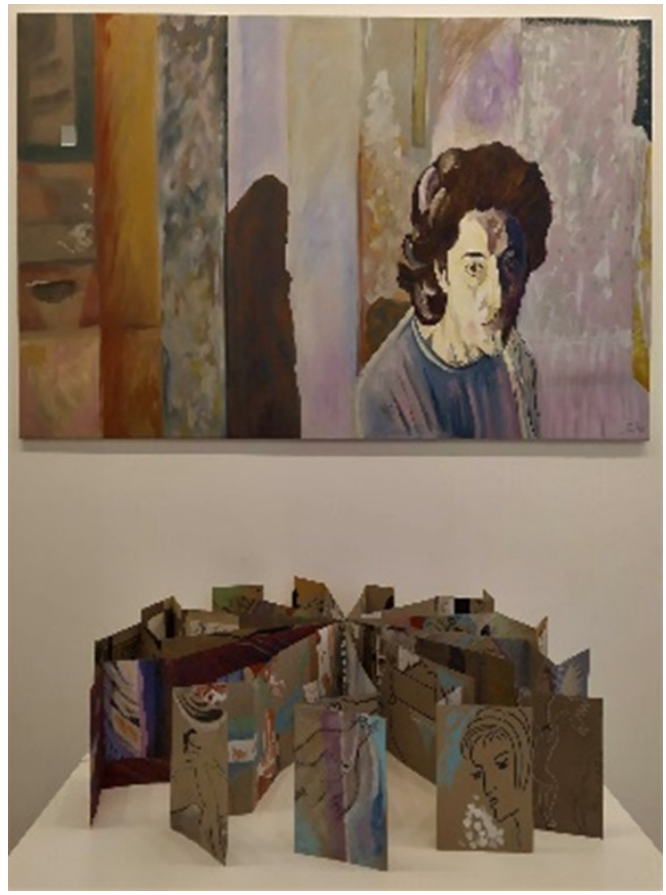

Figura 14 - Celeste Ferreira, "Instalação Águas Livres", óleo s/ tela + livro de artista, $90 \mathrm{~cm} \times 180 \mathrm{~cm}$. 


\title{
As Águas Livres por Celeste Ferreira
}

Falava do encontro consigo, com a face no espelho.

\author{
Por que haveria de ser tão impossível, e \\ aparentemente tão desprezível, ser um pouco \\ feliz? Por que razão o eros se cobria de luto, \\ em lugar de cantar? \\ (GERSÃO, T. As águas livres. Cadernos II. \\ Porto: Porto Editora, 2013. p. 26-27).
}

O que é a autorrepresentação? E o que é a autorrepresentação nas artes plásticas e visuais? Celeste Ferreira (n.1953) tem no seu rosto, na sua expressão e expansão emocional e teórica, o quórum temático da sua pintura. É fazer do suporte espelho da alma e do pensamento e usar a matéria para transformar esse encontro consigo mesma em composição. Pareceu-me como uma fatalidade, desde o primeiro dia, que essa autorrepresentação fosse sempre mais próxima da velhice do que da juventude, do cansaço do que da alegria, numa menção filosófica a um existencialismo que condena a inquietação interior a uma infelicidade latente. No ano em que a premiada escritora Teolinda Gersão (n.1940) assinala 80 anos de vida, dedica-se-lhe obra de arte, em associação a um dos seus livros. Celeste Ferreira escolheu "As águas livres", de 2013, um corrupio de páginas que se engolem e que reúnem a mente a ferver que, em tempos de pandemia, não conseguimos evitar, não conseguimos parar, sossegar. Há, portanto, a coincidência entre as autoras de um olhar para dentro que se expõe na criação artística e/ou literária.

Mas não será toda a criação, autorrepresentação, exposição do eu? Não será sempre sobre nós mesmos o que criamos? Talvez. Celeste Ferreira apropria-se do título, considerando a identificação com a obra de Teolinda Gersão e avança para o campo expandido da pintura, numa busca da quase instalação, associando a uma das suas telas um dos seus livros de artista. Complemento perfeito, pois, que um livro de artista é uma forma de autobiografia plástica feita à mesa, como é a sua pintura. O que há em comum que as torna unas e passíveis de uma só? Tudo. A paleta, o traço, a dinâmica da composição, o rigor dos detalhes que se combinam com a expressão livre e autêntica de quem tem a mão habituada ao desenho e à pintura, a temperatura e, claro, o olhar para dentro. 
Ao longo de um percurso de 45 anos de carreira (considerando que expôs pela primeira vez em 1975 na Galeria do Jornal de Notícias, no Porto), Celeste Ferreira construiu uma certeza do saber fazer e um corpo de trabalho coerente e seguro que lhe permite hoje esvair-se, com confiança, da segurança do bidimensional em busca das novas práticas e das vanguardas do seu tempo que é também este. Com mais de uma centena de exposições, individuais e coletivas, realizadas e com obras em algumas importantes coleções públicas e privadas, Celeste Ferreira parte do mar de Esposende para pensar o mundo e, sobretudo, da linha do horizonte para se pensar e sentir a si própria diante do tal espelho da intempérie e da calma dos dias, a que nos obrigam. Curiosa a paleta, fechada e nostálgica, contrastante com um gesto enérgico e com texturas, por vezes, adensadas com a assemblage e com a coragem da experimentação. Os livros de artista, pelos quais me apaixonei, são também essa coragem e essa energia. Mais: agrada a atenção ao detalhe e o apreço pela manualidade, como recusa pelo exclusivamente digital que, por vezes, é da Arte como é da vida.

Por fim, a plasticidade de Celeste Ferreira encontra a voluptuosidade da escrita de Teolinda Gersão que a incentiva a ser espaço tridimensional, mais do que convite à contemplação pura e monótona da pintura em que se autorrepresenta. Filosoficamente, este é um retrato complexo da mesma mulher, que se reviu na escritora mas que é, sempre, a sua plasticidade e a sua escrita a pincel e à mão. Num tempo de isolamento, o olhar para dentro é obrigatório. Por isso aqui estamos. Não é livre quem não se conhece e não se conhece quem não se mira no tal espelho meditativo dos dias.

Uma vez livre, não mais água de aqueduto, mas corrente que vem da montanha e chega ao mar, como em Esposende.

(Não são estas águas que eu quero, as que o Aqueduto aprisiona. São águas sem margens, limites ou barreiras, sempre nascendo, em movimento, águas sem reflexos, cegas, intactas, tal como chegam pela primeira vez à superfície, deixando-se tocar mas não prender, correndo à procura de si mesmas, fazendo o seu caminho, ao encontro da luz.)

(GERSÃO, T. As águas livres. Cadernos II. Porto: Porto Editora, 2013.p. 68.) 
15.

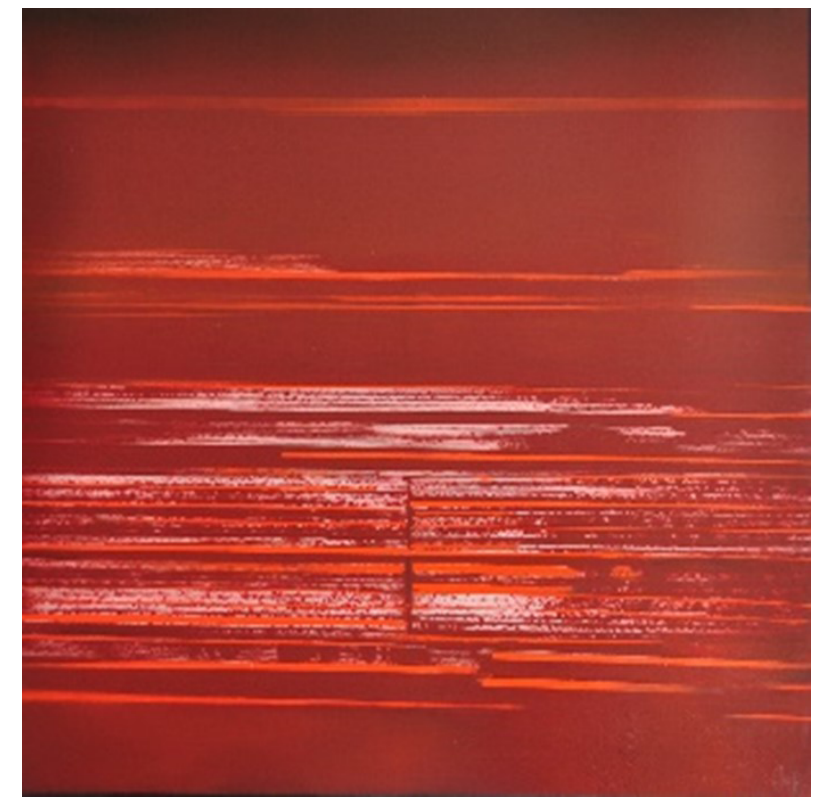

Figura 15 - Eduarda Ferreira, "Passagens", óleo s/ cartão, $79,50 \mathrm{~cm} \times 106,50 \mathrm{~cm}$.

\section{Uma vida de passagem}

Veio parar-me às mãos, recentemente, um pequeno livro da escritora Teolinda Gersão, intitulado "Passagens". Curiosidade natural, dada a profundidade do pensamento desta Senhora, levou-me a fazer uma viagem por algumas das suas criações. E fiquei encantado com o seu "Silêncio", os seus "Prantos, Amores e Desvarios" e vi-me algo perdido e reencontrado nestas suas "Passagens".

A morte do meu filho e da minha mulher originou um desfiar de dias e noites longas a deambular sem rumo, perdido num corpo frequentemente desprovido de alma e cego de cores onde apenas pontuam o negro e o cinza.

Sem conforto nem capaz de a recuperar, encontrei neste ser humano um fugaz luzeiro que me deu a mão e por largos momentos me 
conduziu em direcção ao seu brilho onde, afinal, a minha alma penada se encontrava e onde sempre esteve: bem no seu interior.

Nos dois capítulos iniciais das suas "Passagens" Teolinda percorre o interior das almas dos que ficam e da mãe que partiu. Como uma expectadora invisível no canto daquele quarto, onde Ana jaz, debruçase sobre a realidade e recordações de vidas passadas e ao que elas se resumem. E viaja, de Noite, ao âmago de uma alma prisioneira de uma imaginada e benévola Alzheimer. Uma forma deliciosa de mostrar as várias facetas de vidas comuns que convergem e se afunilam num destino igualmente comum, atingido o qual se vê chegado o momento da suprema e verdadeira análise do percurso construído e vivido por livre arbítrio próprio.

E tem-se saudades, por vezes desespero e constante sofrimento, suplicando por um Alzheimer abençoado que entorpeça a mente e torne o sofredor insensível ao seu Calvário.

Busca-se o bem perdido pelos quatro cantos do Éden onde, de modo infrutífero, se erguem as mãos a um qualquer deus menor e a quem se suplica o que está fora do seu alcance, desacreditado que está o padecente da bondade de o Deus Criador por ele se compadecer. Ou talvez não, pois, por vezes, ou talvez sempre, Ele estendeu o seu manto protector para bem mais próximo, bastando procurar, no sítio certo, o tal conforto oculto no interior de si próprio. E sobrevém a nostalgia.

Tão diáfano tal brilho, este surge com toda a sua luminosidade nestas "Passagens". Talvez possível vertê-las numa tela de cinema pela imaginação humana, torna-se, contudo, impossível mostrá-lo num só frame numa tela de um pintor.

Eduarda Ferreira tentou fazê-lo. Tendo a sua visão da profundidade destas "Passagens", os seus pinceis, qual pena de um escritor, foram desenhando e colorindo uma pantalha e surpreendendo-se com a abstracção a que a mente e a alma da autora a haviam conduzido.

Naquelas suas linhas horizontais, voltando o olhar para a paisagem de um qualquer Douro em viagem num comboio em que esta surge desfocada pela velocidade do trem, assim Eduarda retrata este olhar de fim de vida de Ana onde, num ápice, toda ela decorre com estação final no fogo rubro de um crematório. O sangue e o fogo, bem visível nas cores vermelhas da pintura de Eduarda como términus da passagem de Ana pela terra. 
Por último, ao percorrer as linhas horizontais do quadro, admira-se o seu entrecortado e recomeçado, mais ou menos brilhantes, sulcadas no fundo (e mais profundas), é a sua interpretação das histórias de vida das personagens que cruzam e polvilham a vida de Ana. Passagens de vida da narradora que tão bem Eduarda captou em linhas desenhadas num aparente acaso e que nada mais são que as linhas da vida de qualquer mortal durante a sua existência terrena.

Sentimentos e olhares ao interior de imagens imateriais, possíveis de pintar mas impossíveis de retratar, pois Ana aqui não morre, transcende, é a pintura uma parte intrínseca da obra de Teolinda sem a qual aquela pintura se encontraria desprovida de sentido. Do mesmo modo que "Passagens" se encontra enriquecida perante a imagem quase irrealista da visão de Eduarda.

Uma simbiose perfeita.

Eduarda Ferreira

Para Eduarda Ferreira 
16.

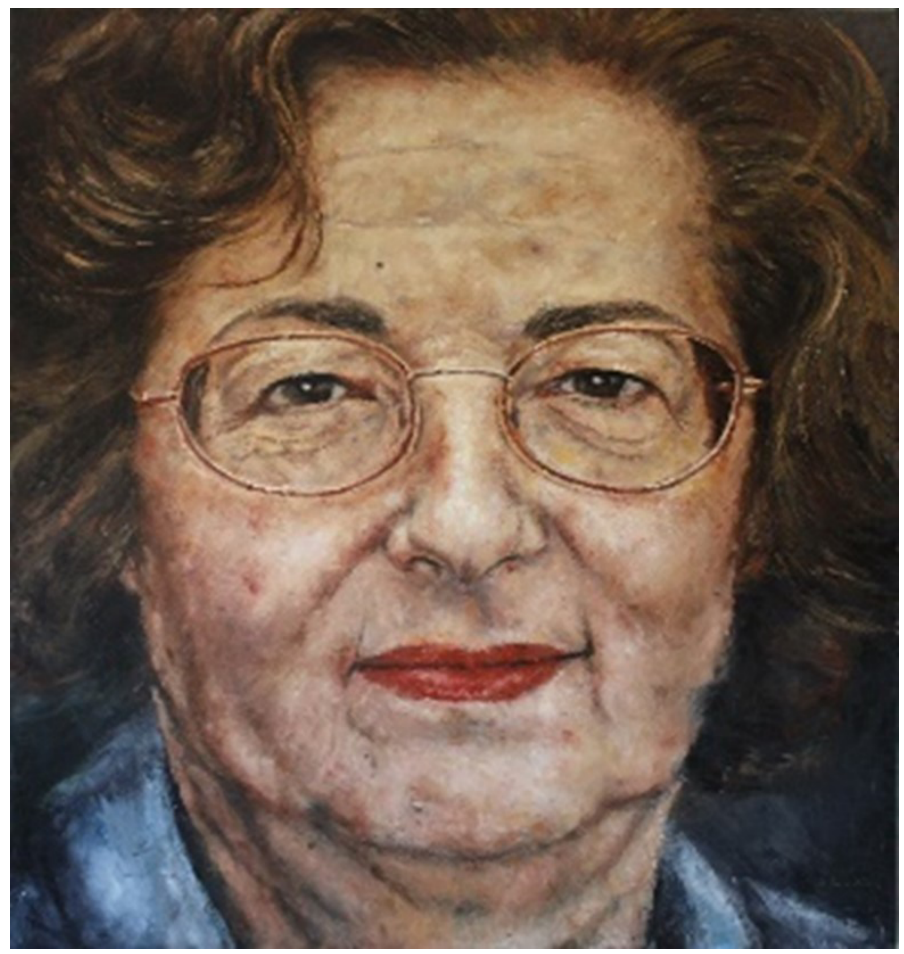

Figura 16 - Do Carmo Vieira, "Teolinda", óleo s/ tela, $120 \mathrm{~cm} \times 100 \mathrm{~cm}$.

\section{Um anjo (não maléfico mas) azul. Uma mulher-anjo}

Um histórico ao nível da objectivação estética de ponderações e explorações identitárias atravessa a obra de Do Carmo Vieira. A artista portadora de grande autoconsciência sócio-profissional, e reconhecendo a transversalidade do retrato nas múltiplas linguagens artísticas, perscruta as personalidades que estimulam a sua vocação retratística. As relações plásticas ficarão sempre (con)fundidas com as sociais e as políticas, também as intelectuais e, particularmente, as literárias. As conexões pintora / modelos configuram sempre um suplemento de significados e, 
ao construí-los, a si própria se constrói. Foi assim com Florbela, Natália e Sophia; fiquemos pelo feminino. É hoje, assertivamente, com Teolinda.

Ouço em Silêncio (1995) as suas palavras e, repentinamente, ultrapassa a barreira do sonho e sinto-a numa tela magnífica que certa espátula violou. Vejo-a ou ao seu retrato? Vejo-a ou à sua escrita? Vejo-a: $120 \times 100$ - óleo sobre tela! Impressões sensuais e visuais decorrem do "impasto" num severo exercício de realidade e dimensionalidade.

Atena ou Minerva, tanto dá! Da Antiguidade chega e permanece num douto saber disponibilizado ao próximo. Agora somos três e continuamos no feminino. Sentamo-nos à sombra de A Árvore de Palavras (1977) falamos de $A$ Cidade de Ulisses (2011). Nesta hora, Os Anjos (2000) deixam As Águas Livres (2013) entoar Prantos, Amores e Outros Desvarios (2016).

Fico só. Observar é um acato solitário. Concentro-me. De Teolinda de Do Carmo Vieira solta-se uma intimidade casual. O brando azul não conflitua com o vermelho fogo, antes aponta para antinomias inerentes ao humano. Metonimicamente, a espátula desliza, espalha a tinta e diz serenidade, doçura, perspicácia. Foi aos livros, ainda metonimicamente, e recuperou na ancestral técnica da daguerreotopia, as várias faces da escritora.

Do Carmo Vieira há muito demonstra que os paradigmas da modernidade não conseguem tornar o retrato obsoleto e, ultrapassando estigmas sociais e estéticos, fez dele, e bem, a sua linha de trabalho aqui e agora enternecida pela elasticidade cultural desta Mulher que prendeu a chuva (2007).

Os grandes retratistas sempre foram evocados conjuntamente com os retratados: Leonardo e "Gioconda", Rafael e "La Fornarina", Velásquez e "Las Meninas", Goya e a "Duquesa de Alba", Picasso e as "Jacquelines", Manet e "Olympia", Monet e "Camille"... Do Carmo Vieira e a sua imensa galeria de artistas portugueses onde, a autora de $O s$ Guarda-Chuvas Cintilantes (1997) tem, por mérito próprio, lugar cativo.

Isabel Ponce de Leão

Para Do Carmo Vieira 


\section{7.}

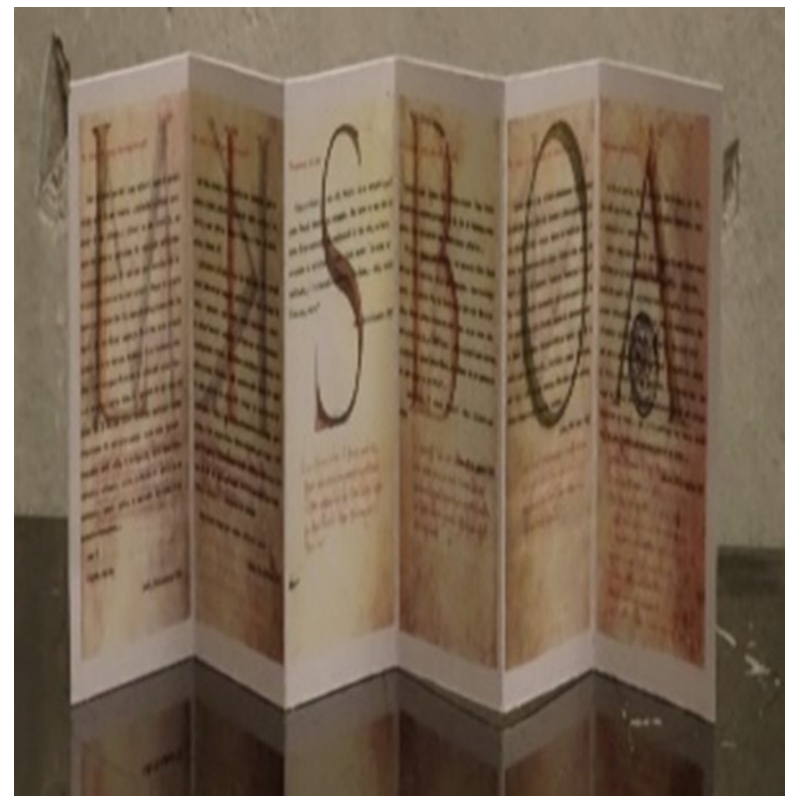

Figura 17 - José Barrias, imagem gráfica com dimensões variáveis. 